\title{
SCHIFF BASE LIQUID CRYSTALLINE COMPOUNDS WITH DISPERSED CITRATE CAPPED GOLD NANOPARTICLES - OPTICAL AND TEXTURAL ANALYSIS
}

\author{
M. Tejaswi ${ }^{1}$, M.C. Rao ${ }^{2}$, R.K.N.R. Manepalli ${ }^{1 *}$, B.T.P. Madhav ${ }^{3}$, \\ P. Pardhasaradhi ${ }^{3}$, G. Giridhar ${ }^{4}$, K. Pandian $^{5}$ and V.G.K.M. Pisipati ${ }^{3}$ \\ ${ }^{1}$ Department of Physics, The Hindu College, Krishna University, Machilipatnam-521001, India \\ ${ }^{2}$ Department of Physics, Andhra Loyola College, Vijayawada-520008, India \\ ${ }^{3}$ LCRC-R\&D, Department of ECE, K L University-522502, Guntur, India \\ ${ }^{4}$ Department of Nanotechnology, Acharya Nagarjuna University, Guntur-522510, India \\ ${ }^{5}$ Department of Inorganic Chemistry, University of Madras, Chennai-600025, India \\ *E-mail: manepalli.67@gmail.com
}

\begin{abstract}
In this paper, $20 \mu \mathrm{l}$ citrate capped Gold $(\mathrm{Au})$ nanoparticles are dispersed in Schiff base Liquid Crystalline compounds $60.0 \mathrm{~m}(\mathrm{~m}=7$ and 9) and characterizations are carried-out to observe the changes occurred with the dispersion of nanoparticles in Liquid Crystalline compounds. The Polarizing Microscopy (POM) technique is used to measure the phase transition temperatures. Differential Scanning Calorimetry (DSC) is used to determine the transition temperatures and enthalpy values. Further characterization is carried-out by Scanning Electron Microscopy (SEM). The nematic transition temperature is decreased by $1{ }^{\circ} \mathrm{C}$ with the dispersion of citrate capped $\mathrm{Au}$ nanoparticles into the Liquid Crystalline compounds. Image processing technique of textural analysis is also carried-out to identify the statistical parameters of the images and their transition temperatures.

Keywords: Liquid Crystal, POM, DSC, Nano-dispersion, SEM and Image processing.
\end{abstract}

(c) RASĀYAN. All rights reserved

\section{INTRODUCTION}

Liquid Crystals (LCs) are playing a vital role in many fields such as displays, optical switches, digital medical imaging etc. ${ }^{1-5}$ because they exhibit isotropic nature like fluid and crystal nature like solid. The alignment of the molecules in long range orientation (i.e. director) with the substrate ${ }^{6,7}$ made these LCs are of very much interest in various fields like Physics, Chemistry, Biology, Pharma, Medicine etc. Moreover, LCs possesses long-range orientational order even with the dispersion of nanoparticles and various colloids ${ }^{8-13}$. Schiff base has been received an overwhelming response in liquid crystals research ever since in 1970 where Kelker discovered the 4-methoxylbenzylidene-4'-butylaniline (MBBA) which exhibit nematic phase at room temperature ${ }^{14}$. Now, MBBA is used as a standard in the liquid crystal in most investigated nematic compound research. Schiff base is a functional group which consists a carbonnitrogen double bond with the nitrogen atom connected to an alkyl or aryl group but not with the hydrogen. The general formula of a typical Schiff base is $\mathrm{R}_{1} \mathrm{R}_{2} \mathrm{C}=\mathrm{N}-\mathrm{R}_{3}$, where $\mathrm{R}_{3}$ is the alkyl or aryl group which make the Schiff base stable imines. Imines can be formed by aromatic amine react with a carbonyl compound by nucleophilic addition with forming a hemiaminal first and followed by dehydration process.

In liquid crystal studies, Schiff base has been used as the linking group where the phase transition temperature and physical properties changes are contributing mainly by the linking group. Though it provides a stepped core structure, it maintains molecular linearity, hence providing higher stability and enabling mesophase formation ${ }^{15}$. Schiff bases are very useful in liquid crystal research because of its rich polymorphism and convenience due to a low temperature of phase transitions ${ }^{16}$. From the literature, it is observed that $\mathrm{nO} . \mathrm{Om}$ compounds exclude 13 various phase transitions from mono variant $(\mathrm{N}, \mathrm{A}$ or $\mathrm{C})$ to 
pentavariant (NACIG). The placement of oxygen atom in molecular structure plays a crucial role in exhibiting the schematic phase, phase variant and richness of temperature. The capping agent helps to prevent the uncontrollable growth of particles, prevent particle aggregation, and control growth rate and particle size. In the present investigation, citrate capped Au nanoparticles are dispersed and characterized in 6O.Om ( $\mathrm{m}=7$ and 9) Schiff base compound. Babu et al. worked with different thermodynamic parameters on $60.0 m$ Schiff base compounds ${ }^{17}$. Au nanoparticles are exhibiting different interesting properties than bulk particles. Even very minute quantities are exhibiting a desirable change by dispersing in LC molecules. Rao et al. published their results on different materials in the earlier studies ${ }^{18-46}$. So in this study, we have made an attempt with the dispersion of citrate capped Au nanoparticles in 60.07 and 60.09 LC compounds to observe the changes in textures, phase transition temperatures and shifts in vibrational bands by POM and DSC.

\section{EXPERIMENTAL}

\section{Synthesis of 60.0m Compounds}

The present $\mathrm{N}$-(p-n-hexyloxy benzylidene) p-n-alkoxy anilines $(6 \mathrm{O} . \mathrm{Om}) \mathrm{LC}$ compounds are synthesized by using respective benzaldehyde and alkoxy anilines according to earlier procedure reported ${ }^{47}$. The corresponding compounds such as $\mathrm{N}$-(p-n-hexyloxy benzylidene) and alkoxyanilines were taken in equimolar proportions and ethanol is used as a solvent and further reflux process has to be done for 3-4 hours by adding few drops of glacial acetic acid. The solvent was removed by distillation process after reflection takes place. The obtained sample should be re-crystallization in presence of ethanol at low temperature to get the pure compound. The structural formula for the obtained compound is as given below-

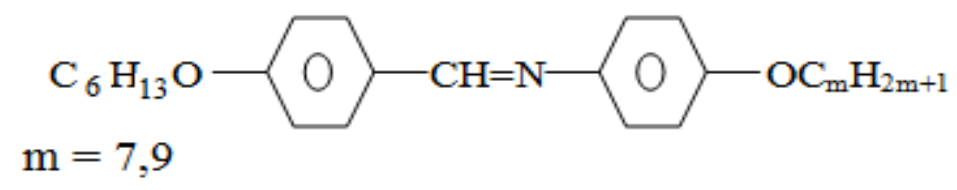

\section{Synthesis of Citrate Capped Au Nanoparticles}

The compounds Auric Chloride $\left(\mathrm{HAuCl}_{4}\right)$ and Tri-sodium Citrate $\left(\mathrm{Na}_{3} \mathrm{C}_{6} \mathrm{H}_{5} \mathrm{O}_{7} \cdot 2 \mathrm{H}_{2} \mathrm{O}\right) 99 \%$ are brought from Sigma-Aldrich laboratories, USA and used as such. By using chemical reduction method Citrate capped $\mathrm{Au}$ nanoparticles are synthesized in the laboratory. First, $20 \mathrm{ml}$ of $1 \mathrm{mM}$ of Auric Chloride is heated and $2 \mathrm{ml}$ of $1 \%$ tri-sodium citrate is added drop by drop and stirred vigorously for two hours. Then the solution changed gradually to red wine color, which indicates the formation of citrate capped $\mathrm{Au}$ nanoparticles.

\section{Synthesis of 60.0m Compound with Dispersed Citrate Capped Au Nanoparticles}

First, the citrate capped Au nanoparticles were dissolved in Toluene, later the nanocomposite solution is stirred well for 45 minutes, an isotropic state of the mesogenic material (6O.07 and 60.09) in quantity 20 $\mu \mathrm{l}$ separately and the complex mixture is stirred about 3 to 4 hours. After cooling, the nanocomposites 60.07 and 60.09 were analyzed by polarizing optical microscope (SDTECHS make) for phase transition temperatures, where the optical microscope is fitted with a hot stage and planar arrangement of $4 \mu \mathrm{m}$ cells. The sample was placed in the cells along with the thermometer. The Textural, phase transition temperatures and enthalpy values of Au nanoparticles were studied by Differential Scanning Calorimeter (Perkin Elmer Diamond DSC). The presence of Au nanoparticles in 6O.Om is studied by SEM data.

\section{POM textures}

\section{RESULTS AND DISCUSSION}

Polarizing Microscope (SDTECHS-SDVPM 2727) is used to observe the transition temperatures and textures of the LC compounds. The textures of 60.07 pure and 60.07 with dispersed $20 \mu 1$ citrate capped Au nanoparticles are shown in Fig.1(a-c) and Fig.2(a-c) whereas textures of 60.09 pure and 60.09 with dispersed $20 \mu \mathrm{l}$ citrate capped Au nanoparticles are shown in Fig.3(a-c) and Fig. 4(a-c). 


\section{POM textures of 60.07 Pure}

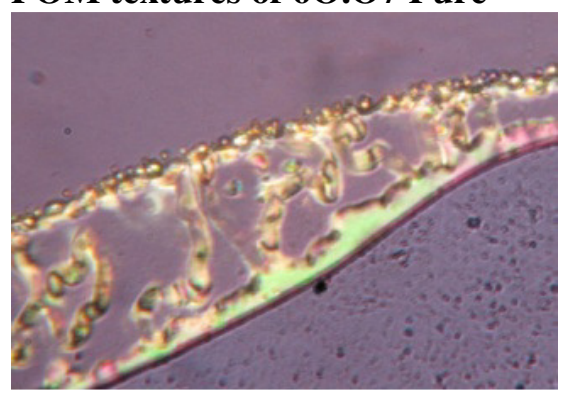

Fig.-1a: Isotropic-nematic phase at $110.5^{\circ} \mathrm{C}$

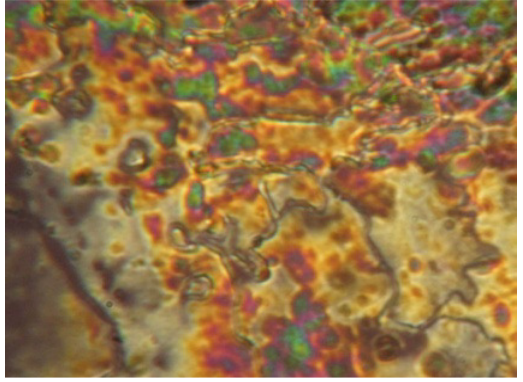

Fig.-1b: Nematic phase at $100.9^{\circ} \mathrm{C}$

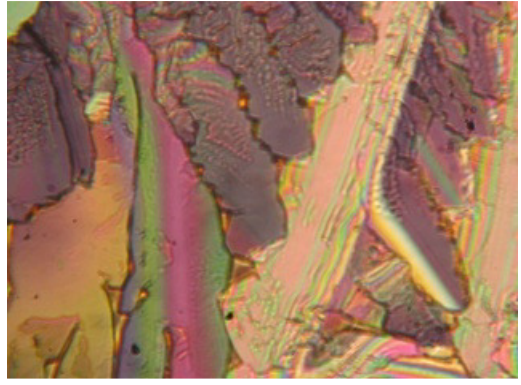

Fig.-1c: Solid phase at $55.2^{\circ} \mathrm{C}$

\section{POM textures of $60.07+20 \mu \mathrm{l}$ citrate capped Au nanoparticles}

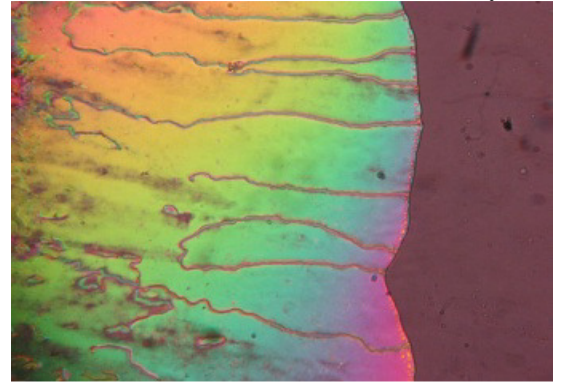

Fig.-2a: Isotropic-nematic phase at $109.7^{\circ} \mathrm{C}$

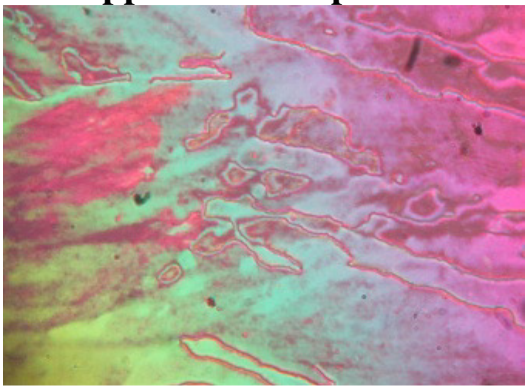

Fig.-2b: smectic C phase at 105.3 ${ }^{\circ} \mathrm{C}$

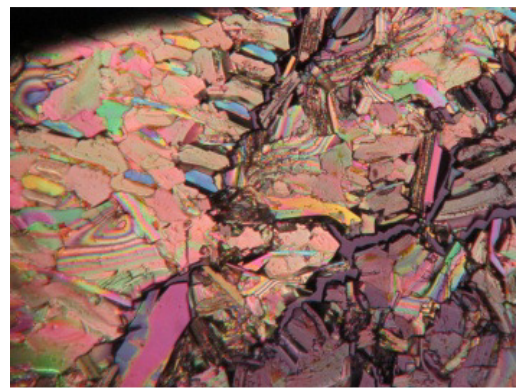

Fig.-2c: Solid phase at $94.7^{\circ} \mathrm{C}$

\section{POM textures of 60.09 Pure}

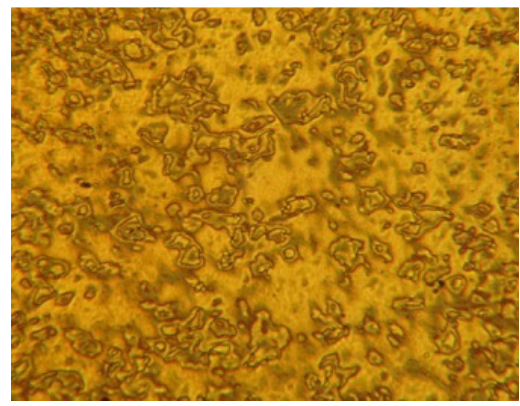

Fig.-3a: Isotropic - nematic phase at $111.9^{\circ} \mathrm{C}$

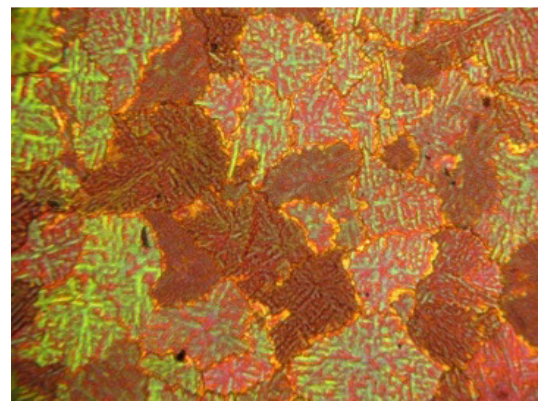

Fig.-3b: smectic C phase at $102.2^{\circ} \mathrm{C}$

\section{POM textures of $60.09+20 \mu \mathrm{l}$ citrate capped Au nanoparticles}

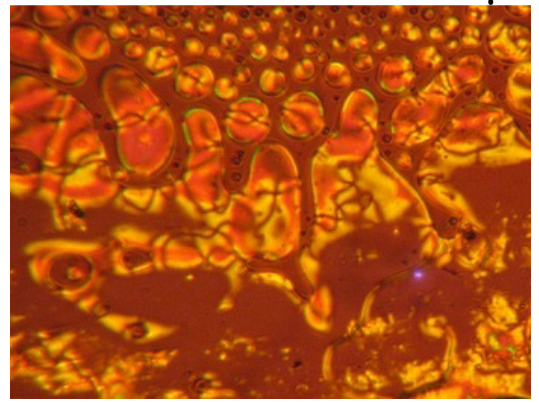

Fig.-4a: Isotropic - nematic phase at $101.9^{\circ} \mathrm{C}$

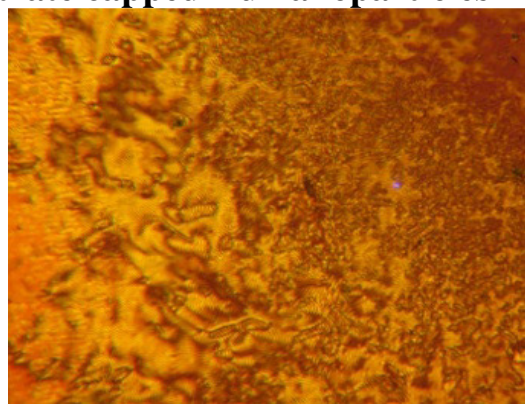

Fig.-4b: smectic C phase at $90.1{ }^{\circ} \mathrm{C}$

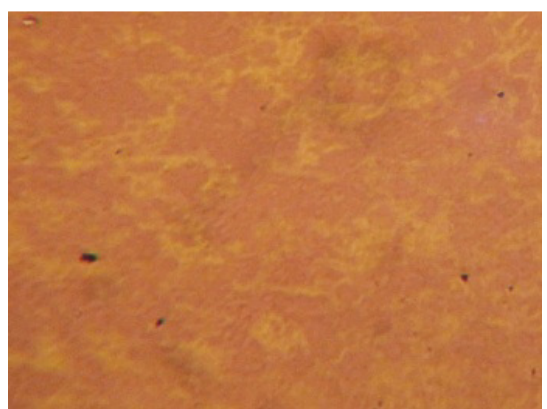

Fig.-3c: Solid I at $63.5^{\circ} \mathrm{C}$

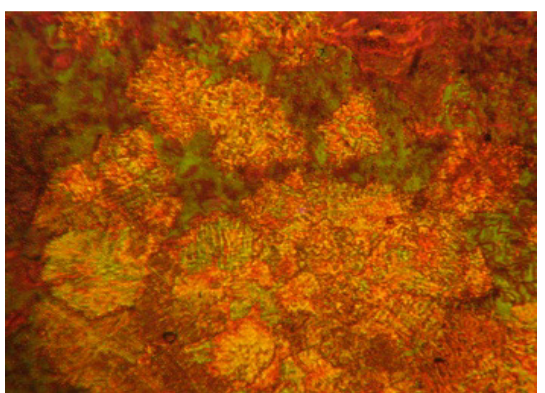

Fig.-4c: Solid I at $60.5^{\circ} \mathrm{C}$ 
The DSC thermograms of 6O.O7 with $20 \mu \mathrm{l}$ citrate capped Au nanoparticles and 60.09 with $20 \mu 1$ citrate capped Au nanoparticles are shown in Fig.5 and Fig.6. The nematic transition temperature has decreased slightly and nematic thermal range has increased with the dispersion of citrate capped Au nanoparticles (Table-1).

\section{SEM analysis}

SEM is used to study the morphological surface of the sample and also gives the crystallographic information such as grain size and shape. The SEM images of 60.09 with the dispersion of $20 \mu \mathrm{l}$ citrate capped Au nanoparticles are shown in Fig.-8. A very few nm resolution can be obtained from SEM about 10X - 300,000X. Results from the energy dispersive spectroscopy (EDS) reveal the presence of chemical compounds in the sample. Carbon $(\mathrm{C})$, Gold $(\mathrm{Au})$ and oxygen $(\mathrm{O})$ elements are present in the 60.09 with dispersed citrate capped Au nanoparticle sample. From EDS (Fig.7) data, the presence of nanoparticles in the compound is well established (Table-2).

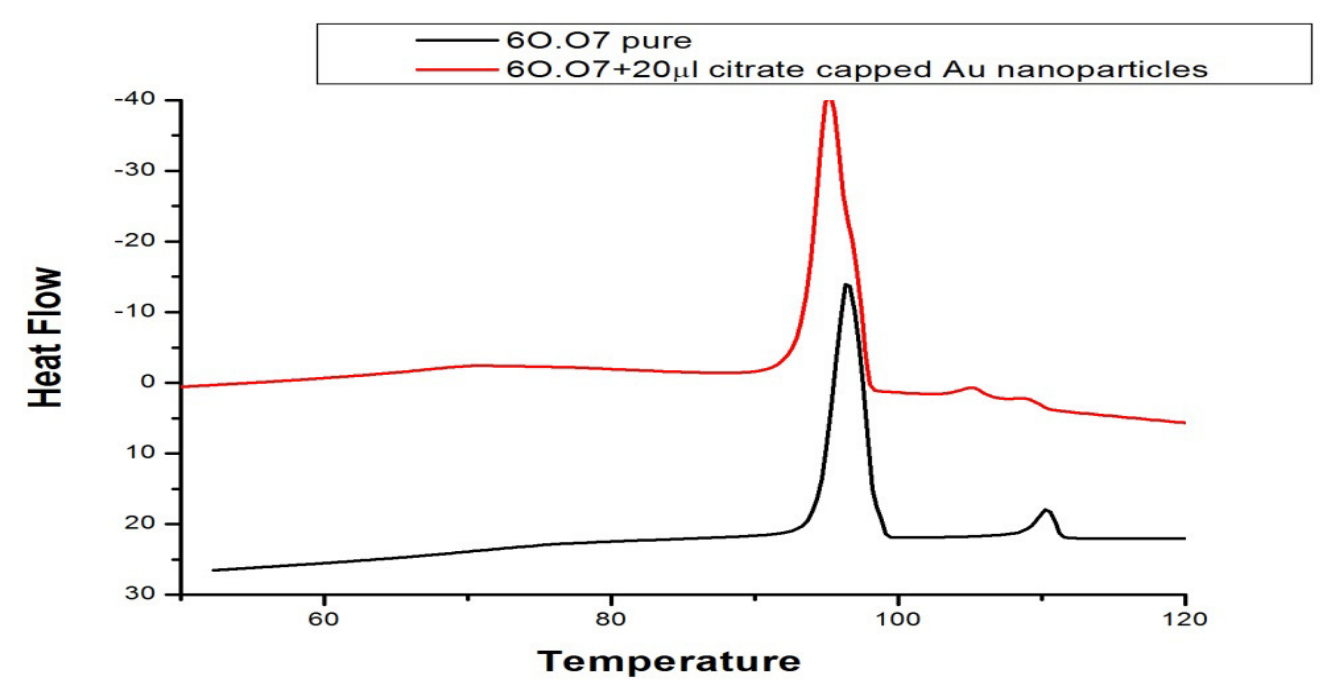

Fig.-5: DSC thermogram of 60.07 pure with dispersed $20 \mu 1$ citrate capped Au nanoparticles

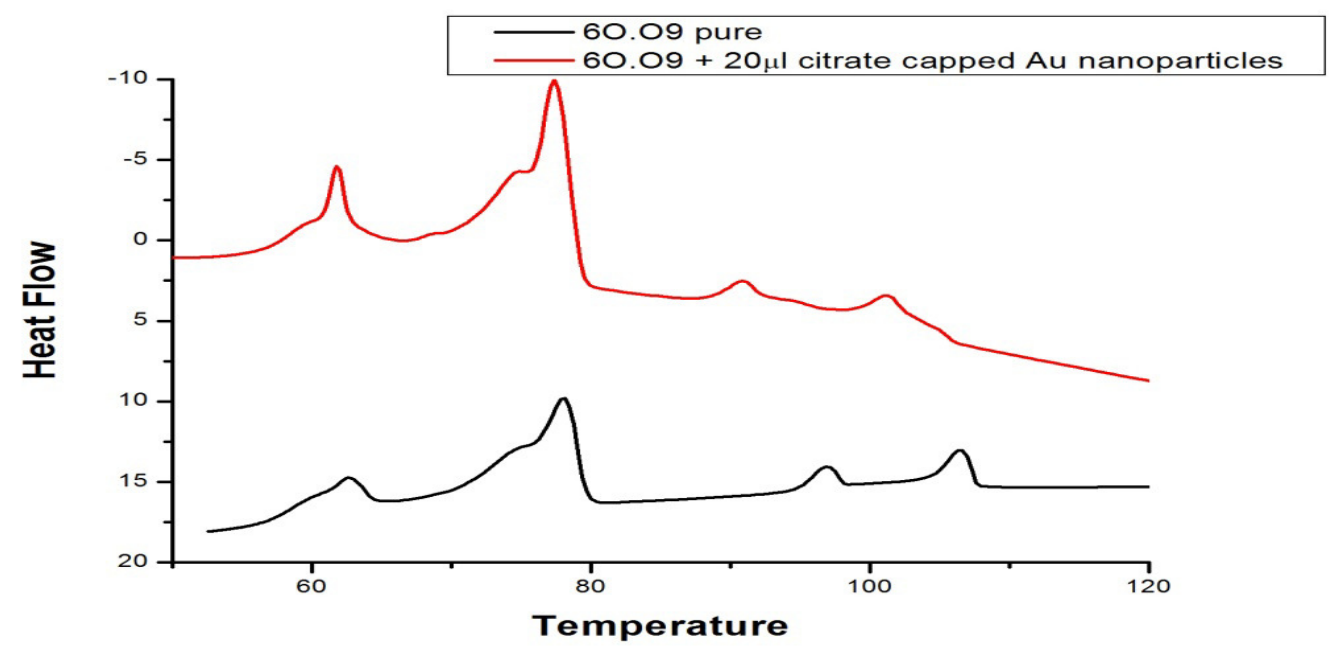

Fig.-6: DSC thermogram of $6 \mathrm{O} .09$ pure with dispersed $20 \mu 1$ citrate capped Au Nanoparticles 
RASĀYAN J. Chem.

Vol. 10 | No. 1 |69-76 | January - March | 2017

Table-1: Phase variants and transition temperatures of 60.07 and 60.09 pure and with dispersed $20 \mu 1$ citrate capped Au nanoparticles

\begin{tabular}{|c|c|c|c|c|c|c|c|c|}
\hline \multirow[t]{2}{*}{ S.No. } & \multirow[t]{2}{*}{ Compound } & \multirow{2}{*}{$\begin{array}{l}\text { DSC/ } \\
\text { POM }\end{array}$} & \multirow{2}{*}{$\begin{array}{l}\text { Scan } \\
\text { Rate }\end{array}$} & \multicolumn{4}{|c|}{ Transition Temperatures ${ }^{\circ} \mathrm{C}$} & \multirow{2}{*}{$\begin{array}{c}\text { Nematic } \\
\text { Therma } \\
\text { range }\end{array}$} \\
\hline & & & & I-N & $\begin{array}{l}\text { NSmC/ } \\
\text { SmI }\end{array}$ & $\begin{array}{l}\text { SmC- } \\
\text { SolidI }\end{array}$ & $\begin{array}{c}\text { SolidI - } \\
\text { Solid II }\end{array}$ & \\
\hline \multirow[t]{2}{*}{1} & \multirow[t]{2}{*}{ 6O.O7PURE } & DSC & $\begin{array}{l}20^{\circ} \\
\mathrm{C} / \mathrm{min}\end{array}$ & 110.28 & ------- & 55.67 & & \\
\hline & & POM & & 110.5 & $\begin{array}{l}------- \\
\end{array}$ & 55.2 & & \\
\hline \multirow[t]{2}{*}{2} & \multirow{2}{*}{$\begin{array}{l}6 \mathrm{O} . \mathrm{O} 7+20 \mu \mathrm{l} \text { citrate } \\
\text { capped } \mathrm{Au} \\
\text { nanoparticles }\end{array}$} & DSC & $\begin{array}{l}20^{\circ} \\
\mathrm{C} / \mathrm{min}\end{array}$ & 109.20 & 105.27 & 95.25 & & 3.93 \\
\hline & & POM & & 109.7 & 105.3 & 94.7 & & 4.4 \\
\hline \multirow[t]{2}{*}{3} & \multirow[t]{2}{*}{ 60.09 PURE } & DSC & $\begin{array}{l}20^{\circ} \\
\mathrm{C} / \mathrm{min}\end{array}$ & 111.74 & 102.34 & 88.56 & 62.1 & 9.4 \\
\hline & & POM & & 111.9 & 102.2 & 88.9 & 63.5 & 9.7 \\
\hline \multirow[t]{2}{*}{4} & \multirow{2}{*}{$\begin{array}{c}60.09+20 \mu 1 \text { citrate } \\
\text { capped } \mathrm{Au} \\
\text { nanoparticles }\end{array}$} & DSC & $\begin{array}{l}20^{\circ} \\
\mathrm{C} / \mathrm{min}\end{array}$ & 101.31 & 90.86 & 77.38 & 61.78 & 10.45 \\
\hline & & POM & & 101.9 & 90.1 & 76.5 & 60.5 & 11.8 \\
\hline
\end{tabular}

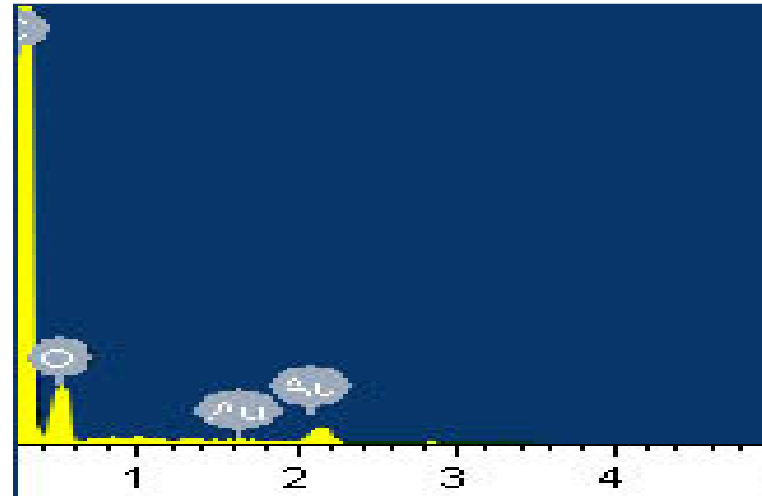

Fig.-7: EDS data of $6 \mathrm{O} .09$ with dispersed $20 \mu \mathrm{l}$ citrate capped Au nanoparticles

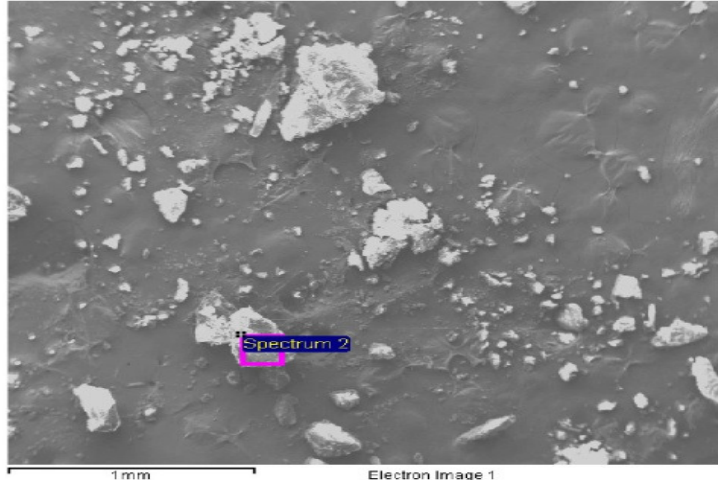

Fig.-8: SEM Image of 60.09 with dispersed $20 \mu 1$ citrate capped Au nanoparticles

Table-2: EDS data

\begin{tabular}{c|c|c}
\hline Element & Weight\% & Atomic\% \\
\hline $\mathrm{C} \mathrm{K}$ & 83.27 & 89.65 \\
\hline $\mathrm{O} \mathrm{K}$ & 12.46 & 10.07 \\
\hline $\mathrm{Au} \mathrm{M}$ & 4.27 & 0.28 \\
\hline
\end{tabular}

\section{Textural Analysis with Statistical Parameters}

The texture is a repeatable unit with having a regular frequency. Various types have been provoked in the visual interpretation of texture such as smooth, fine, coarse etc. which are widely used in the classification of forest types. The textural analysis is mainly dependent on its classification and it can be defined by segmentation of textural features with respect to the shape of a small element, density, and direction of regularity. A difficulty has been raised in the case of the digital image due to its mathematical texture because the volume of textural data is so large as well as it is not standardized quantitatively. The statistical approach explores the statistical parameters of image regions in a bottom up fashion, starting from the pixel values in the neighborhood. The brief descriptions regarding statistical parameters are presented in Table-3 and shown in Fig.-9. 
RASĀYAN J. Chem.

Vol. 10 | No. 1 |69-76 | January - March | 2017

The co-occurrence matrix is widely used for representing the distributions of gray-level functions: (1) the image region, (2) a displacement vector $d=(d x, d y)$, (3) the number of gray-levels after quantization. The textural matrix with having frequencies contains the co-occurrence of two gray-levels. After normalization, it becomes a probability matrix with all the elements summing up to 1 . A large number of features based on co-occurrence matrices, such as contrast, homogeneity, correlation, energy, and entropy can be considered as statistical parameters of a digital image. The statistical parameters will help us to identify the phase transition in the compound by finding its mean. Over the temperature range, the images collected from the POM will be considered to find the statistical parameter mean. Image processing with Matlab will provide the transition temperatures of the compound without taking the help of DSC ${ }^{48-50}$. The time and cost will be reduced to find the transition temperatures of the images through image processing technique.

Table-3: Statistical Parameters

\begin{tabular}{|c|c|c|}
\hline PARAMETER & DESCRIPTION & FORMULA \\
\hline CONTRAST & $\begin{array}{l}\text { Returns the measures of intensity } \\
\text { contrast between a pixel and its } \\
\text { neighbor over the whole image. } \\
\text { Range }=\left[0(\text { size }(\mathrm{GLCM})-1)^{2}\right] \\
\text { When the gray } 2 \text { levels of each pixel } \\
\text { pair are similar, the Contrast is } \\
\text { expected to be low and Contrast is } 0 \\
\text { for a constant image. }\end{array}$ & $\sum_{i, j}|i-j|^{2} P(i, j)$ \\
\hline HOMOGENEITY & $\begin{array}{l}\text { Measures the local homogeneity of a } \\
\text { pixel pair. The Homogeneity is } \\
\text { expected to be large if the gray levels } \\
\text { of each pixel pair are same. } \\
\text { Range=[ll } 1 \text { 1 }\end{array}$ & $\sum_{i, j} \frac{P(i, j)}{1+|i-j|}$ \\
\hline CORRELATION & $\begin{array}{l}\text { Returns a measure of how correlated a } \\
\text { pixel is to its neighbor over the whole } \\
\text { image. } \\
\text { Range }=\left[\begin{array}{ll}-1 & 1\end{array}\right] \\
\text { The Correlation is expected to be high } \\
\text { if the gray levels of the pixel pairs are } \\
\text { highly correlated. }\end{array}$ & $\sum_{i, j} \frac{(i-\mu i)(j-\mu j) p(i, j)}{\sigma_{i} \sigma_{j}}$ \\
\hline ENERGY & $\begin{array}{l}\text { Measures the number of repeated } \\
\text { pairs. The Energy is expected to be } \\
\text { high if the occurrence of repeated } \\
\text { pixel pairs is high. Energy is one for a } \\
\text { constant image. }\end{array}$ & $\sum_{i, j} P(i, j)^{2}$ \\
\hline ENTROPY & $\begin{array}{l}\text { Statistical measure of randomness that } \\
\text { can be used to characterize the texture } \\
\text { of the input image. The entropy is } \\
\text { expected to be high if the gray levels } \\
\text { are distributed randomly throughout } \\
\text { the image. }\end{array}$ & $-\sum_{i, j} P(i, j) \log (p(i, j))$ \\
\hline
\end{tabular}




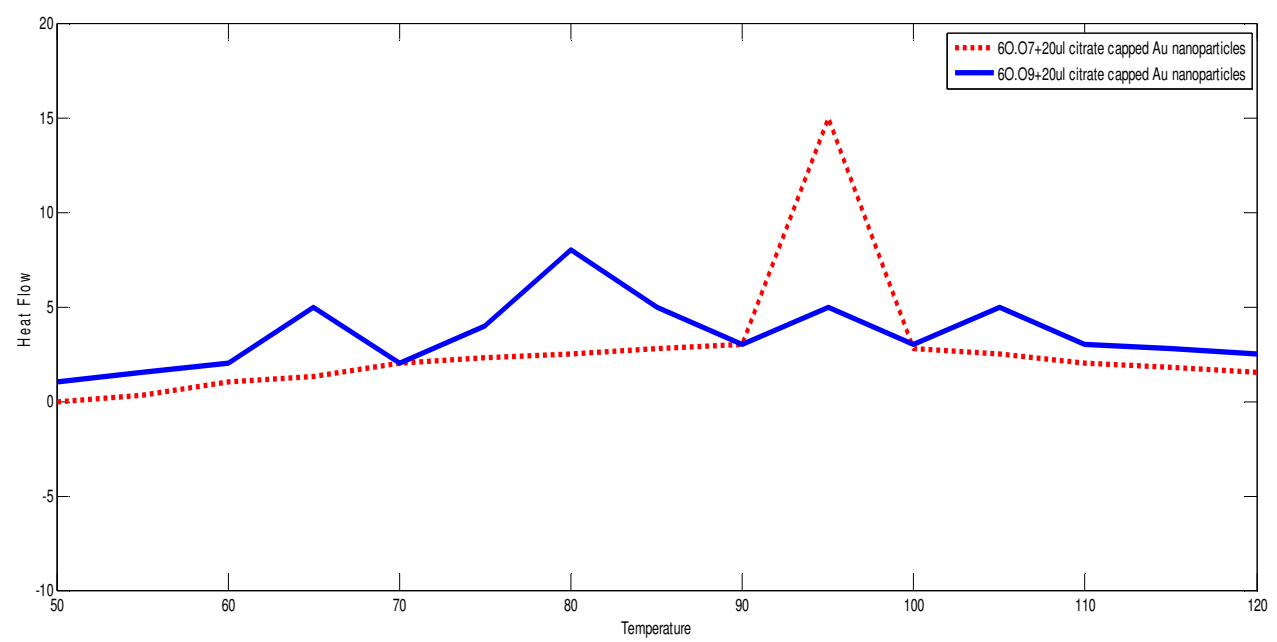

Fig.-9: Statistical parameters based image processing data of mean for nanodispersed 60.0 compounds

\section{CONCLUSION}

With the dispersion of citrate capped Au nanoparticles in 60.07 and 60.09 LC compounds, the changes in textures, phase transition temperatures and shifts in vibrational bands by POM and DSC are observed. The transition temperatures obtained from both POM and DSC are in good agreement. The nematic transition temperature has decreased and nematic thermal range has increased with a dispersion of citrate capped $\mathrm{Au}$ nanoparticles in LC compound. The existence of citrate capped Au nanoparticles in LC compounds is strongly confirmed by SEM data. The proposed technique (textural analysis with statistical parameters) will provide the information regarding transition temperature of the compound without taking the help of DSC instrument. The mean of all the images collected at different temperatures is utilized for finding the phase change in this method. Image processing based statistical parameters will help to get the transition data of the compound in less time and at low cost.

\section{ACKNOWLEDGEMENT}

The Corresponding author Dr. R.K.N.R. Manepalli (Dr. M. Ramakrishna Nanchara Rao) is thankful to the UGC for grant 42-784/2013 (SR).

\section{REFERENCES}

1. D. Venkata Rao, P. Pardhasaradhi and V.G.K.M. Pisipati, Phase Transit., 88, 137 (2015).

2. P.S. Sastry, Ch. Srinivasu and P. Pardhasaradhi, Phase Transit., 89, 37 (2016).

3. P.S. Sastry, P. Pardhasaradhi and Ch. Srinivasu, Liquid Cryst., 43, 632 (2016).

4. R.K.N.R. Manepalli, P. Perdhasaradhi, B. T. P. Madhav, P. Jayaprada and V.G.K.M. Pisipati, J. Earth Sci. Engg., 9, 25 (2016).

5. K.P. Androie, J. Amer. J. Am. Coll. Radio., 2, 543 (2005).

6. P.G. de Gennes and J. Prost, The Physics of Liquid Crystals, second ed., Clarendon, Oxford(1993).

7. K. Takatoh, M. Hasegawa, M. Koden, N. Itoh, R.Hasegawa and M. Sakamoto, Alignment Technologies and Application of Liquid Crystals Devices, Taylor \&Francis, New York (2004).

8. Y. Shiraishi, N. Toshima, K. Maeda, H. Yoshikawa, J. Xu and S. Kobayashi, Appl. Phys. Lett., 81, 2845 (2002).

9. M.D. Lynch and D.L. Patrick, Nano Lett., 2, 1197 (2002).

10. I. Dierking, G. Scalia and P.J. Morales, J. Appl. Phys., 97, 044309 (2005).

11. R. Basu and G. Iannacchione, Appl. Phys. Lett., 93, 183105 (2008).

12. J.P.F. Lagerwall and G. Scalia, J. Mater. Chem., 18, 2890 (2008). 
13. J.M. Russell, S. Oh, I. LaRue, O. Zhou and E.T. Samulski, Thin Solid Films, 509, 53 (2006).

14. Z. Galewaki, Mol. Cryst. Liq. Crystal., 249, 43 (1994).

15. G.Y. Yeap, S.T. Ha and P.L. Lim, Mol. Cryst. Liq. Crystal., 452, 63 (2006).

16. P.J. Collings and M. Hird, Introduction to liquid crystals chemistry and physics. London:Taylor and Francis (1998).

17. R. Babu and G. Iannacchione, Phys. Rev. E, 106, 124312 (2009).

18. J. Sivasri, M.C. Rao, G. Giridhar, B.T.P. Madav, T.E. Divakar, R. K.N.R. Manepalli, Rasayan J.Chem., 9(4), 556 (2016).

19. P. Jayaprada, 588 M. Tejaswi, G. Giridhar, M.C. Rao, V.G.K.M. Pisipati, R.K.N.R Manepalli, Rasayan J. Chem., 9(4), 588 (2016).

20. M. Tejaswi, M.C. Rao, P.V. Datta Prasad, G. Giridhar, V.G.K.M. Pisipati, R.K.N.R. Manepalli, Rasayan J. Chem., 9(4), 697 (2016).

21. M.C. Rao, J. Crys. Growth, 312(19), 2799 (2010).

22. M.C. Rao, K. Ramachandra Rao, Int. J. Chem.Tech Res., 6(7), 3931 (2014).

23. M.C. Rao, Optoelect. \& Adv. Mater (Rapid Commu.), 5, 85 (2011).

24. Sk.Muntaz Begum, M.C. Rao and R.V.S.S.N. Ravikumar, Spectrochim. Acta Part A: Mol. \& Biomol. Spec., 98, 100 (2012).

25. M.C. Rao, J. Optoelect. \& Adv. Mater., 13, 428 (2011).

26. M.C. Rao, O.M. Hussain, Eur. Phys. J. Appl. Phys., 48(2), 20503 (2009).

27. Sk. Muntaz Begum, M.C. Rao and R.V.S.S.N. Ravikumar, J. Inorg. Organometa. Poly. Mater.,23(2), 350 (2013).

28. MC Rao, J. Optoelect. \& Adv. Mater., 12, 2433 (2010).

29. M.C. Rao, O.M. Hussain, IOP Conf. Series: Mater. Sci. Eng., 2, 012037, (2009).

30. M.C. Rao, O. M. Hussain, Ind. J. Eng. Mater. Sci., 16, 335 (2009).

31. K. Ravindranadh, M.C. Rao, R.V.S.S.N. Ravikumar, J. Mater. Sci: Mater. Elect., 26, 6667 (2015).

32. M.C. Rao, Optoelect. \& Adv. Mater. (Rapid Commu.), 5(5-6), 651 (2011).

33. M.C. Rao, O.M. Hussain, Optoelect. \& Adv. Mater., 13(2-4), 1109 (2011).

34. K. Ravindranadh, B. Babu, C.V. Reddy, J. Shim, M.C. Rao, R. Ravikumar, Appl. Mag. Reson. 46 (1), 1 (2015).

35. MC Rao, OM Hussain, Res. J. Chem. Sci., 1(7), 92 (2011).

36. M.C. Rao, Int. J. Chem. Sci., 10(2), 1111 (2012).

37. M.C. Rao, Optoelect. \& Adv. Mater. (Rapid Commu.), 6, 511 (2012).

38. M.C. Rao, J. Optoelect. \& Adv. Mater., 13, 78 (2011).

39. K. Ravindranadh, M.C. Rao and R.V.S.S.N. Ravikumar, J. Luminesce., 159, 119 (2015).

40. M.C. Rao, Sk. Muntaz Begum, Optoelect. \& Adv. Mater. (Rapid Commu.), 6, 508 (2012).

41. M.C. Rao, K. Ravindranadh, T. Satyanarayana, Y. Dasaradhudu, Der Pharm. Che., 8(4), 243 (2016).

42. M.C. Rao, Optoelect. \& Adv. Mater. (Rapid Commu.), 4, 2088 (2010).

43. K. Sivaram, M.C. Rao, G. Giridhar, M. Tejaswi, B.T.P. Madhav, V.G.K.M. Pisipati, R. K. N. R. Manepalli, Rasayan J. Chem., 10(1), 16 (2017).

44. M.C. Rao, K. Ravindranadh, M.S. Shekhawat, AIP Conf. Proc., 1728(1), 020077 (2016).

45. M.C. Rao, K. Ravindranadh, AIP Conf. Proc., 1349, 641 (2011).

46. M.C. Rao, K. Ravindranadh, D. Sridhar Kumar, Int. J. ChemTech Res., 9(4), 598 (2016).

47. P. Kelker and B. Scheurle, Angew. Chem. Int. Ed. Engl., 8, 884 (1969).

48. M. Rambabu, K. R. S. Prasad, B. T. P. Madhav and M. Venu Gopalarao, J. Engg. Appl. Sci., 11, 1 (2016).

49. M. Rambabu, K. R. S. Prasad, M. Venu Gopala Rao, B. T. P. Madhav and V. G. K. M. Pisipati, Liquid Crys. Today, 24, 81 (2015).

50. B.T.P. Madhav, P. Pardhasaradhi, R.K.N.R. Manepalli, P.V.V. Kishore and V.G.K.M. Pisipati, Liquid Crystals, 37, 41 (2015).

[RJC-1571/2017] 